\title{
Actisil application affects growth, flowering, and biochemical parameters in petunia in vitro and greenhouse
}

\author{
Marcelina Krupa-Małkiewicz $^{1}$ (D) Mario Calomme ${ }^{2}$
}

Received: 31 December 2020 / Accepted: 3 April 2021 / Published online: 20 April 2021

(c) The Author(s) 2021

\begin{abstract}
Mineral nutrients are necessary for the growth and development of plants. Previous studies have concentrated mainly on silicon-accumulating plants, while less work has been conducted on non-accumulating plants such as Petunia $\times$ atkinsiana D. Don. In this study, we investigated the responses of morphological (plant height, root length, fresh and dry weight, no. of flowers) and biochemical (proline, malondialdehyde MDA, catalase CAT activity, total chlorophylls, carotenoids, total polyphenol, and $\mathrm{NO}_{3}$ ) traits of petunia to external application of commercial silicon solution (Hydroplus ${ }^{\mathrm{TM}}$ Actisil) after 5 weeks of in vitro culture and 6 weeks under greenhouse condition. Actisil was supplemented into the MS medium (in vitro) at concentrations of 0 (control), 50,100,200, and $500 \mathrm{mg} \mathrm{L}^{-1}$, or supplied via irrigations at a concentration of 0 (control) and $200 \mathrm{mg} \mathrm{L}^{-1}$ in one, two, and three applications under greenhouse conditions. The addition of silicon to the MS medium decreased plant height (22-41\% of control) and root length (53-70\% of control). In contrast, in greenhouse-grown petunia irrigation of silicon increased plant height (145\% of control ) and root length (176\% of control). Petunias treated with Actisil had greener leaves compared to the control. This was also confirmed by higher concentrations of chlorophyll. Conversely, increased concentrations of proline, MDA, and total polyphenol and higher CAT activities may indicate that silicon provokes a stress response of the in vitro plants. Actisil treatment in the concentration of $200 \mathrm{mg} \mathrm{L}^{-1}$ was found to positively affect the growth and flowering of the greenhouse-grown petunia.
\end{abstract}

\section{Key message}

Actisili application in vitro may provoke a stress response of the Petunia $\times$ atkinsiana D. Don. plantlets, but under greenhouse the concentration of $200 \mathrm{mg} \mathrm{L}^{-1}$ positively affected the growth and flowering of petunia.

Keywords Petunia $\times$ atkinsiana D. Don $\cdot$ Colour $\cdot$ CAT activity $\cdot$ Nitrates $\cdot$ Total polyphenols $\cdot$ Silicon

\section{Introduction}

Plant tissue culture is used as a tool for the study of various basic problems in plant science (Sivanesan and Won Park 2014; Sahebi et al. 2016; Krupa-Małkiewicz and

Communicated by T. Winkelmann.

Marcelina Krupa-Małkiewicz

mkrupa@zut.edu.pl

1 Department of Plant Genetics, Breeding and Biotechnology, West Pomeranian University of Technology Szczecin, Słowackiego 17 Street, Szczecin, Poland

2 Research \& Development/Regulatory Affairs, BIO MINERALS N.V., Zenderstraat 12, 9070 Destelbergen, Belgium
Smolik 2019). The effectiveness of the multiplication process depends on many factors. Most often the composition of the medium is modified, to stimulate the growth of particular plant material. Inadequate mineral composition of the nutrient solution can lead to growth disorders and plant growth anomalies, and even hyperhydricity, shoot tip necrosis, or hooked leaves (Sivanesan and Won Park 2014).

Silicon ( $\mathrm{Si}$ ) is the second most abundant mineral nutrient, after oxygen in the soil (Sivanesan and Won Park 2014; Sahebi et al. 2016; Luyckx et al. 2017; Boldt et al. 2018). Silicon is mainly present in soil solution as silicic acid $\left(\mathrm{H}_{4} \mathrm{SiO}_{4}\right)$ in concentrations of $0.1-0.6 \mathrm{mM}$. This mineral is easily absorbed from the soil, thus terrestrial plants contain it to a significant extent, i.e. $0.1-10 \%$ or more of dry matter (Boldt et al. 2018). Therefore, each plant rooted in the soil takes up silicon in the form of silicic acid $\left(\mathrm{Si}(\mathrm{OH})_{4}\right)$ through its roots 
and accumulates it in its tissues. Because this element occurs naturally in the soil and the effects of deficiency or toxicity on plants are hardly visible, increasing research on the effect of silicon on plants is being conducted. According to many authors, (Sivanesan and Won Park, 2014; Sahebi et al. 2016; Shekari et al. 2017; Boldt et al. 2018), silicon is involved in many life processes, and the reaction of plants to environmental factors. Moreover, in numerous plant species, the beneficial effects of silicon on growth, development, yield, and disease resistance have been observed. According to many authors (Vaculik et al. 2009; Sahebi et al. 2016; Luyckx et al. 2017; Mandlik et al. 2020) silicon increases the tolerance of plants to abiotic and biotic stresses by increasing the activity of antioxidant enzymes, the secretion of endogenous hormones, and the production of lignins, chitinase, phenolic compounds, phytoalexins, and glucanases. Furthermore, silicon has positive impacts seen as increased dry weight, higher rates of photosynthesis, increased flower size, and earlier flowering (Boldt et al. 2018).

Plants can be classified as $\mathrm{Si}$ accumulators or non-accumulators (Epstein 1994; Boldt et al. 2018). Numerous authors have studied whether silicon supplementation will benefit nonaccumulators. In the study of Epstein (1994) plants with a low silicon content in the tissue were shown to grow normally when a silicon deficit existed in the soil or medium. However, species for which silicon is not essential may grow better in media containing high silicon than in media with a silicon deficit.

Most greenhouse-grown ornamental plants are considered low Si accumulators or non-accumulators (Boldt et al. 2018). Petunia (Petunia $\times$ atkinsiana D. Don) is classified as a nonaccumulator of $\mathrm{Si}$ (Frantz et al. 2011). It is a widely cultivated bedding plant and one of the most popular ornamental plants in the horticultural trade (Krupa-Małkiewicz et al. 2017). Besides, its importance as an ornamental plant, the petunia has proved to be an excellent model plant for research on gene regulation, genome structure, and biochemical analysis (Vandenbussche et al. 2016; Druege and Franken 2019; KrupaMałkiewicz and Smolik 2019). Due to the important role of the Solanaceae family in agronomic and ornamental crops, in the present study the effect of $\mathrm{Si}$, applied as a commercial Hydroplus $^{\mathrm{TM}}$ Actisil solution, on petunia was investigated under in vitro and greenhouse conditions. Effects on the morphological (plant height, root length, fresh and dry weight, no. of flowers) and biochemical (proline, malondialdehyde MDA, catalase CAT activity, total chlorophylls, carotenoids, total polyphenol, and $\mathrm{NO}_{3}$ ) traits were analysed.

\section{Materials and methods}

\section{Laboratory studies}

Petunia $\times$ atkinsiana D. Don cultivar Prism White already established in vitro, was sectioned in two-leaf explants measuring 15-20 mm long. The explants were transferred to MS medium according to Murashige and Skoog's (1962) composition of vitamins, macro- and microelements. MS medium was supplemented with a commercial Hydroplus $^{\mathrm{TM}}$ Actisil (Yara, Poland) solution in concentrations of $0,50,100,200$, and $500 \mathrm{mg} \mathrm{L}^{-1}$. The composition of Actisil given by the producer was $\mathrm{Si}-0.6 \%, \mathrm{Ca}-2 \%$, $\mathrm{H}_{2} \mathrm{O}-35-45 \%$, Choline $-55-65 \%$ and the recommended dose is an application of the solution in a concentration of $200 \mathrm{mg} \mathrm{L}^{-1}$. Each combination included 48 shoots (four shoots per flask in twelve replications). All media were supplemented with $30 \mathrm{~g} \mathrm{~L}^{-1}$ sucrose (Chempur, Poland) and $100 \mathrm{mg} \mathrm{L}^{-1}$ myo-inositol (Duchefa, The Netherlands) and were solidified with $8 \mathrm{~g} \mathrm{~L}^{-1}$ agar (Biocorp, Poland), $\mathrm{pH}$ of the media was adjusted to 5.7. The media were heated and $30 \mathrm{ml}$ were poured into a $450 \mathrm{ml}$ flask and next they were autoclaved at $121{ }^{\circ} \mathrm{C}(0.1 \mathrm{MPa})$ during the time required according to the volume of medium in the vessel. All cultures were incubated in a growth room at a temperature of $24 \pm 2{ }^{\circ} \mathrm{C}$ under $16 \mathrm{~h}$ photoperiod with a photosynthetic flux density (PPFD) of $40 \mu \mathrm{mol} \mathrm{m}{ }^{-2} \mathrm{~s}^{-1}$ provided by Narva (Germany) emitting daylight cool white. After the end of the experimental period (five weeks), explants were removed and washed with deionized distilled water, and the lengths of the shoots and roots were measured, and the number of flowers was counted. The plants were weighed for estimation of plant (shoot and root) fresh mass and then dried at $70{ }^{\circ} \mathrm{C}$ for $48 \mathrm{~h}$. The dried plants were weighed to record a plant dry mass. The dry mass of explants was determined after drying in the hot-air oven at $70{ }^{\circ} \mathrm{C}$ for $24 \mathrm{~h}$.

\section{Greenhouse experiment}

Explants were initially selected under in vitro culture, and then made adaptive to greenhouse conditions in the second half of April 2019. The plantlets with well-developed shoots and roots were transferred into round black plastic pots the diameter of $9 \mathrm{~cm}$, filled with soil (deacidified peat + soil) at $\mathrm{pH} 5.5$, mixed with vermiculate in $1: 1$ ratio. The pots were placed on $60-\mathrm{cm}$ high tables in the greenhouse at $20^{\circ} \mathrm{C} / 15^{\circ} \mathrm{C}$ day/night temperature cycles and light intensity of $110 \mathrm{~mol} \mathrm{~m}^{-2} \mathrm{~s}^{-1}$ during the experimental period. The temperature inside the greenhouse was 
controlled by vents that opened automatically. After 10 days of the transplantation, the plants were irrigated with $100 \mathrm{ml}$ per pot of the $200 \mathrm{mg} \mathrm{L}^{-1}$ solution of Hydroplus ${ }^{\mathrm{TM}}$ Actisil in combinations: for 1 week, 2 , and 3 weeks. Control plants were irrigated with $100 \mathrm{ml}$ of distilled water. Each treatment was repeated weekly intervals. This experiment was arranged as a complete randomized block design (CRBD), 3 replications per treatment and each replication comprised 5 plants ( 15 plants per treatment). The petunia plants were grown until six weeks. On the last day of the experiment, plants were removed from the pots, rinsed in tap water, and the morphological parameters were determined: shoot and root length $(\mathrm{cm})$, and the number of shoots and flowers per plant. The plants were weighted for estimation of whole plants (shoot and root) fresh mass $(\mathrm{g})$ and dry mass $(\mathrm{g})$.

\section{Silicon content in plants}

The samples $(100 \mathrm{mg})$ from in vitro and greenhouse were digested with acid $\left(33 \% \mathrm{HNO}_{3}\right)$ in a microwave system under high pressure. The $\mathrm{Si}$ concentration was measured by Electrothermal Atomic Absorption Spectrometry with inverse longitudinal Zeeman background correction (Perkin Elmer. Analyst 800) and pyro-coated graphite tubes with a L'vov platvorm (Perkin Elmer).

\section{Analysis of proline and malondialdehyde (MDA)}

The concentration of proline was determined according to the method of Bates et al. (1973) using spectrophotometer at $520 \mathrm{~nm}$ in petunia fresh leaves and calculated as $\mu \mathrm{mol} \mathrm{g}$ fw. The content of the malondialdehyde (MDA, a product of lipid peroxidation) in plant tissue was determined by the method described by Sudhakar et al. (2001). The concentration of MDA was calculated from the absorbance at 600 , 532, and $450 \mathrm{~nm}$, and MDA contents were estimated using the following Equations:

MDA $\left(\mathrm{nmol} \cdot \mathrm{g}^{-1} \mathrm{fw}\right)=[6.45 \times(\mathrm{A} 532-\mathrm{A} 600)-0.56$ A450] $\times$ V/fw.

where: $\mathrm{V}$ - volume of the sample, A - absorbance, fw - fresh weight.

\section{Determination of the content of the pigments}

The concentration of total chlorophylls (chlorophyll $a+b$ ) and carotenoid were determined spectrophotometrically at 663,645 , and $440 \mathrm{~nm}$. The content of chlorophylls was calculated according to Arnon et al. (1956) in modification to Lichtenthaler and Wellburn (1983) derived by Hendry and Grime (1993). Carotenoid content was determined according to Price and Henry (1991).

\section{Determination of catalase (CAT) activity (EC 1.11.1.6)}

The catalase (CAT) activity was determined according to the method by Lück (1963). The decrease in absorbance, caused by the decomposition of $\mathrm{H}_{2} \mathrm{O}_{2}$, was monitored continuously at $240 \mathrm{~nm}$ for $90 \mathrm{~s}$. One unit of enzyme is the amount necessary to decompose $1 \mu \mathrm{M} \mathrm{H}_{2} \mathrm{O}_{2} \mathrm{~g}^{-1} \mathrm{fw} \min ^{-2}$.

\section{The total polyphenol contents (TPC)}

The TPC was determined spectrophotometrically by using a Folin-Ciocalteu reagent. The standard curve was calculated using gallic acid as standard, and the absorbance was measured spectrophotometrically at $700 \mathrm{~nm}$ and expressed as $\mathrm{mg}$ of gallic acid equivalents (GAE) per mg $100 \mathrm{~g}^{-1}$ of plant material.

\section{Leaf pigments estimation}

The leaves (from the middle part of the shoot) pigments estimation was carried out using spectrophotometer CM700d (Konica Minolta, Japan). Measurements were made in CIE $L^{*} a^{*} b^{*}$ system (Hunterlab 2012). The $10^{\circ}$ observer type and D65 illuminant were applied. Colour was measured in triplicates for each experimental combination.

\section{Statistical analysis}

All statistical analyses were performed using Statistica 13.0 (StatSoft, Cracow, Poland). Statistical significance of the differences between means was determined by testing the homogeneity of variance and normality of distribution, followed by ANOVA with Tukey's post hoc test. The significance was set at $p<0.05$. The relationship between morphological (plant height, root length, fresh and dry weight, no of flower) and biochemical (proline, MDA, total chlorophylls, carotenoids, CAT activity, total polyphenol, $\mathrm{NO}_{3}$ ) traits of petunia plants grown under in vitro and greenhouse condition of the results obtained were subjected to agglomerative cluster analysis and classified into groups in a hierarchical order using Ward's method. 


\section{Results and discussion}

\section{Effect of silicon on in vitro and greenhouse development and growth of petunia}

Silicon ( $\mathrm{Si}$ ) plays an important role in the structural rigidity of cell walls. When plants have passive or selective assimilation or they are poor accumulators, such as Solanaceae, the percentage of silicon absorbed and present in the plants is lower than $1 \%$, but its presence can provide significant benefits to the plant growth (Luyckx et al. 2017; Boldt et al. 2018; Mandlik et al. 2020).

The effect of commercial silicon solution (Hydroplus ${ }^{\mathrm{TM}}$ Actisil) supplementation on petunia morphological traits (plant height, root length, and the number of flowers) propagated in vitro varied depending on its concentrations (Table 1). It was observed that concentrations of 50, 100, and $500 \mathrm{mg} \mathrm{L}^{-1}$ statistically decreased plant height from 41 to $22 \%$, in comparison to the control plants. Also, $50 \mathrm{mg} \mathrm{L}^{-1}$ of Si solution statistically decreased the root length, which was 53\% shorter than that of untreated plants. The use of Actisil solution did not affect the fresh and dry weight of whole (shoot and root) petunia explants, with results similar to that of the untreated plants (control). However, plants treated with 200 and $500 \mathrm{mg} \mathrm{L}^{-1}$ had higher fresh and dry weight, but the means were not statistically different from the control (Table 1). Actisil also stimulated reproductive responses.

Table 1 Effect of different concentrations of silicon (Actisil) in the MS medium on morphological traits of petunia plants under in vitro conditions after 5 weeks of culture ( $n=48$ shoots per treatments)

\begin{tabular}{llllll}
\hline $\begin{array}{l}\text { MS + Actisil } \\
\left(\mathrm{mg} \mathrm{L}^{-1}\right)\end{array}$ & $\begin{array}{l}\text { Plant } \\
\text { height } \\
{[\mathrm{cm}]}\end{array}$ & $\begin{array}{l}\text { Root } \\
\text { length } \\
{[\mathrm{cm}]}\end{array}$ & $\begin{array}{l}\text { Fresh } \\
\text { weight } \\
{[\mathrm{g}]}\end{array}$ & $\begin{array}{l}\text { Dry } \\
\text { weight } \\
{[\mathrm{g}]}\end{array}$ & $\begin{array}{l}\text { No of } \\
\text { flowers }\end{array}$ \\
\hline 0 & $2.00 \mathrm{a}^{*}$ & $14.0 \mathrm{a}$ & $1.94 \mathrm{a}$ & $0.19 \mathrm{a}$ & $0.27 \mathrm{~b}$ \\
50 & $1.18 \mathrm{~b}$ & $7.36 \mathrm{~b}$ & $1.25 \mathrm{a}$ & $0.14 \mathrm{a}$ & $0.64 \mathrm{ab}$ \\
100 & $1.27 \mathrm{~b}$ & $8.14 \mathrm{ab}$ & $1.81 \mathrm{a}$ & $0.16 \mathrm{a}$ & $0.37 \mathrm{~b}$ \\
200 & $1.82 \mathrm{ab}$ & $9.55 \mathrm{ab}$ & $2.03 \mathrm{a}$ & $0.23 \mathrm{a}$ & $0.91 \mathrm{a}$ \\
500 & $1.55 \mathrm{~b}$ & $9.81 \mathrm{ab}$ & $2.21 \mathrm{a}$ & $0.20 \mathrm{a}$ & $0.55 \mathrm{ab}$ \\
\hline
\end{tabular}

* Means followed by the same letter do not differ significantly at $\mathrm{p}=0.05$ according to Tukey multiple range
The highest number of flowers (0.91) was observed in petunia plants propagated on MS medium with the addition of Actisil in a concentration of $200 \mathrm{mg} \mathrm{L}^{-1}$ (Table 1).

Actisil supplementation resulted in a significant linear increase in plant height, the number of shoots, root length, and the number of flowers of the greenhouse-grown petunia plants, in response to increasing commercial silicon solution treatment (Table 2). The plants treated three times were $45 \%$ taller, had $40 \%$ more shoots and their roots were $76 \%$ longer compared to control plants (not treated with silicon solution). Also, it was observed that Actisil had an effect on the number of flowers that were formed only after the irrigation of the Si solution, and their number increased linearly as the number of Actisil applications increased (Table 2; Fig. 1). Although no significant response of fresh and dry weight to Actisil was observed, the plants after applying silicon solution three times had 25 and $107 \%$ higher fresh and dry weight, respectively, compared to the control. Our results, and the reported literature (Epstein 1994; Boldt et al. 2018), indicated that annual bedding plant height and root length can be increased by silicon solution treatment and its application. The differences in the effect of Actisil on plant shoot and root growth under in vitro and greenhouse conditions may be explained that in the in vitro system, the starting material was nodal explants. Thus, adventitious roots needed to be formed. By contrast, the starting material in the greenhouse condition was rooted plantlets of petunia. There was no need for regeneration of roots from shoot tissue. This difference may also explain the strong inhibition of root length in vitro, which contrasted to a positive effect of Actisil on root length in the greenhouse-grown petunia. According to Druege and Franken (2019) cutting or explants are highly disturbed structures because they have to cope with wounding and isolation from donor plant, particularly from the root system. However, the mechanism of the supplementation effect of Si on plant height is unclear (Voogt and Sonneveld 2001; Kamenidou et al. 2008). Whitted-Haag et al. (2014) reported that silicon foliar application influenced the growth and quality characteristics of selected bedding plants (i.e., geranium, impatiens, pansy, petunia, and snapdragon). However, effects were evident depending on the concentration of Si treatments and applications. In their studies, they

Table 2 Effect of number of $200 \mathrm{mg} \mathrm{L}^{-1}$ silicon (Actisil) applications on morphological traits of greenhouse-grown petunia plants at the end of experiment $(\mathrm{n}=15$ plants per treatment)

\begin{tabular}{|c|c|c|c|c|c|c|}
\hline $\begin{array}{l}\text { Number of } 200 \mathrm{mg} \mathrm{L}^{-1} \text { Actisil } \\
\text { applications }\end{array}$ & Plant height $[\mathrm{cm}]$ & Number of shoots & Root length $[\mathrm{cm}]$ & Fresh weight $[\mathrm{g}]$ & Dry weight $[\mathrm{g}]$ & No of flowers \\
\hline 0 & $15.5 b^{*}$ & $1.0 \mathrm{a}$ & $4.84 \mathrm{~b}$ & $4.87 \mathrm{a}$ & $0.97 \mathrm{a}$ & $0 \mathrm{~b}$ \\
\hline 1 & $17.5 \mathrm{~b}$ & $1.2 \mathrm{a}$ & $6.60 \mathrm{ab}$ & $5.32 \mathrm{a}$ & $1.62 \mathrm{a}$ & $0.4 \mathrm{ab}$ \\
\hline 2 & $17.8 \mathrm{~b}$ & $1.6 \mathrm{a}$ & $8.0 \mathrm{a}$ & $5.96 \mathrm{a}$ & $1.86 \mathrm{a}$ & $0.6 \mathrm{ab}$ \\
\hline 3 & $22.5 \mathrm{a}$ & $1.4 \mathrm{a}$ & $8.5 \mathrm{a}$ & $6.10 \mathrm{a}$ & $2.01 \mathrm{a}$ & $1.5 \mathrm{a}$ \\
\hline
\end{tabular}

*Means followed by the same letter do not differ significantly at $\mathrm{p}=0.05$ according to Tukey multiple range 
observed significant linear decreases in plant height in petunia in response to increasing foliar Si treatment. Braga et al. (2009) investigated the effects of $\mathrm{Si}\left(1 \mathrm{~g} \mathrm{~L}^{-1}\right.$ of $\mathrm{Na}_{2} \mathrm{SiO}_{3}$; $\mathrm{CaSiO}_{3}$; and $\mathrm{K}_{2} \mathrm{SiO}_{3}$ ) on the anatomical characteristics of strawberry seedlings (Fragaria $\times$ ananasa) cultivated on MS medium. The fresh and dry weight and the chlorophyll content of the seedlings increased in MS medium with the addition of sodium silicate. Moreover, the addition of $1 \mathrm{~g}$ $\mathrm{L}^{-1} \mathrm{Na}_{2} \mathrm{SiO}_{3}$ in the MS medium resulted in increased thickness of leaf tissues and epicuticular wax deposition and increased silicon deposit in the cells. Similarly, the fresh and dry weight of banana seedlings increased when cultured in the MS supplemented with $\mathrm{Na}_{2} \mathrm{SiO}_{3}$, and the chlorophyll content increased when cultured in the MS with the addition of $\mathrm{CaSiO}_{3}$ (Asmar et al. 2013). Silicon application has been found to increase the root number and the growth of Cattleya loddigesii seedlings grown in modified Knudson medium supplemented by $\mathrm{Na}_{2} \mathrm{SiO}_{3}\left(20 \mathrm{mg} \mathrm{L}^{-1}\right)$ and $\mathrm{K}_{2} \mathrm{SiO}_{3}(5 \mathrm{mg}$ $\mathrm{L}^{-1}$ ) (Soares et al. 2011). According to da Silva et al. (2020), silicon efficiency depends on the different sources and the specific concentrations. In their studies, they confirmed the highest efficiency of $0.25 \mathrm{mg} \mathrm{L}^{-1} \mathrm{CaSiO}_{3}$ in MS medium in shoots regenerated in vitro of gerbera plants, in comparison to $\mathrm{Na}_{2} \mathrm{SiO}_{3}, \mathrm{~K}_{2} \mathrm{SiO}_{3}$, and $\mathrm{H}_{4} \mathrm{SiO}_{4}$.

The cluster analysis carried out using Ward's method (Fig. 2a, b) identified two groups with a similar influence on the morphological parameters of the petunia plants. This may indicate that the plants' growth was highly dependent on the place of cultivation (greenhouse or in vitro). In the in vitro system (Fig. 2a), plantlets grown on MS medium supplemented with silicon solution (group b) showed a significant influence of Actisil on the morphological traits tested compared to control (group a). In the case of greenhouse-grown petunia (Fig. 2b), a significant effect of Actisil applied in 3 doses on the morphological traits was confirmed. A completely separate group b were plants treated three times by Actisil.

\section{Silicon and nitrate contents}

Si has been detected in all tissue (shoot and root) samples derived from plants supplied with Actisil, but the value varied with its concentration. In the in vitro grown plants, the highest concentration $(0.0922 \%)$ was detected when MS medium was supplemented with $100 \mathrm{mg} \mathrm{L}^{-1}$ Actisil. The other petunia plantlets had $\mathrm{Si}$ concentrations between 0.713 and $0.821 \%$ and were from 122 to $155 \%$ higher than the control (Fig. 3A). By comparison, in the control greenhousegrown petunia, Si content was at the lowest level $(0.008 \%)$. It was noted that the concentration of $\mathrm{Si}$ in greenhousegrown petunia increases linearly in response to the number of Actisil applications, and ranged from 0.09 to $0.14 \%$ (Fig. 3b).

Mattson and Leatherwood (2010) reported, that petunia plants had the lowest Si concentration of all of the plants tested in their study. When drenched with $100 \mathrm{mg} \mathrm{L}^{-1} \mathrm{Si}$, it was able to accumulate $140 \%$ more Si than the control plants (211 $\mathrm{mg} \mathrm{L}^{-1}$ ). They also suggested that baseline leaf Si concentration was not indicative of potential Si uptake. Boldt et al. (2018) observed that addition to the substrate of $20 \%$ of $\mathrm{Si}$ as a parboiled rice hull, increased Si concentration by $7 \%$ in petunia flowers (Petunia $\times$ hybrida 'Dreams Pink'), 105\% in stems, and $115 \%$ in leaves; however, a significant increase of $687 \%$ was found in the root. Frantz et al. (2008) reported that detection of $\mathrm{Si}$ in plants depends on quantification methods. They used three methods of Si detection in a petunia plant grown on Hogland's solution and none was found in the control plants. However, in leaves of petunia treated with $2.0 \mathrm{mM}$ of $\mathrm{K}_{2} \mathrm{SiO}_{4}$, when using the ICP-OES (Inductively Cayled Plasma - Optical Emission Spectoscopy) method the concentration of Si was 5.8\%; when using the EBA (Electron Beam Analysis) system, it was 197.3\%; and when using the colorimetric method, it was $237.8 \%$.

Nitrate $\left(\mathrm{NO}_{3}\right)$ are not a major health risk to consumers. The presence of these compounds results from fertilization but also the natural nitrogen cycle. Additionally, cultivation on peat soils, which are rich in organic matter, leads to a higher accumulation of nitrates in plants (Ochmian et al. 2020). In MS medium, nitrate ions concentration is known. The content of nitrate in the plantlets under in vitro culture was lower than that in the greenhouse-grown plants. It was noticed, that in petunia plantlets under in vitro culture the content of $\mathrm{NO}_{3}$ ranged from 78 to $1000 \mathrm{~g}^{-1}$ (MS with $500 \mathrm{mg} \mathrm{L}^{-1}$ Actisil) to $125 \mathrm{mg} 1000 \mathrm{~g}^{-1}$ (MS with $50 \mathrm{mg} \mathrm{L}^{-1}$ Actisil) (Table 3). It was noted that, the higher concentration of Actisil in the MS medium, the lower $\mathrm{NO}_{3}$ content. A similar relationship was observed in the case of the application of $\mathrm{Si}$ solution under greenhouse conditions. However, the content of $\mathrm{NO}_{3}$ in greenhouse-grown petunia ranged from 174 to $1000 \mathrm{~g}^{-1}$ (control) to $328 \mathrm{mg} 1000 \mathrm{~g}^{-1}$ (after one-time Actisil irrigation) (Table 4).

According to numerous authors (Franklin et al. 2000; Zhang 2007; Krupa-Małkiewicz and Mgłosiek 2016), various levels of nitrates may act as a signal to induce flowering in vitro. Despite this, there is limited published research on the effects of silicon on plant flowering. Results obtained by Savvas et al. (2002) suggest that in hydroponically grown gerbera (Gerbera jamesomii) the inclusion of $\mathrm{Si}$ in the nutrient solution improves flowers number and quality. In the current study, plantlets grown on MS with the addition of $200 \mathrm{mg} \mathrm{L}^{-1}$ developed the highest number of flowers (0.9) per plant (Table 1). In the case of greenhouse-grown plants, the highest number of the flower was observed after third irrigation of $200 \mathrm{mg} \mathrm{L}^{-1}$ Actisil (Table 2; Fig. 1). 
Table 3 Effect of different concentrations of silicon (Actisil) in the MS medium on biochemical traits of petunia plants under in vitro conditions after 5 weeks of culture $(n=48$ shoots per treatments)

\begin{tabular}{|c|c|c|c|c|c|c|c|}
\hline $\begin{array}{l}\text { MS + Actisil } \\
\left(\mathrm{mg} \mathrm{L}^{-1}\right)\end{array}$ & $\begin{array}{l}\text { Proline } \\
\left(\mu \mathrm{mol} \mathrm{g} \mathrm{g}^{-1} \mathrm{fw}\right)\end{array}$ & $\begin{array}{l}\text { MDA (nmol } \\
\left.\mathrm{g}^{-1} \mathrm{fw}\right)\end{array}$ & $\begin{array}{l}\text { Total chloro- } \\
\text { phylls }\left(\mu \mathrm{g} \mathrm{g}^{-1}\right. \\
\text { fw) }\end{array}$ & $\begin{array}{l}\text { Carotenoid } \\
\left(\mu \mathrm{g} \mathrm{g}^{-1} \mathrm{fw}\right)\end{array}$ & $\begin{array}{l}\text { Catalze CAT }(\mu \mathrm{M} \\
\left.\mathrm{H}_{2} \mathrm{O}_{2} \mathrm{~g}^{-1} \text { fw } \min ^{-2}\right)\end{array}$ & $\begin{array}{l}\text { Total polyphenol } \\
\mathrm{mg}\left(\mathrm{GAE} 100 \mathrm{~g}^{-1}\right)\end{array}$ & 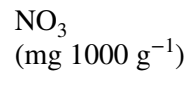 \\
\hline 0 & $2,13 a^{*}$ & $12,2 \mathrm{a}$ & $1,45 \mathrm{a}$ & $0,78 \mathrm{~d}$ & $42,1 \mathrm{ab}$ & $231,8 \mathrm{a}$ & $114 \mathrm{c}$ \\
\hline 50 & $5,34 \mathrm{~b}$ & $15,4 a b$ & $1,62 \mathrm{ab}$ & $0,51 b c$ & $37,8 \mathrm{a}$ & $255,6 \mathrm{ab}$ & $125 \mathrm{c}$ \\
\hline 100 & $6,41 b$ & $19,0 \mathrm{~b}$ & $2,33 \mathrm{c}$ & $0,60 \mathrm{c}$ & $44,5 b$ & $273,1 b$ & $97 b$ \\
\hline 200 & $24,60 \mathrm{c}$ & $28,6 \mathrm{c}$ & $2,58 \mathrm{c}$ & $0,23 \mathrm{a}$ & $50,2 \mathrm{c}$ & $322,6 \mathrm{c}$ & $85 \mathrm{ab}$ \\
\hline 500 & $27,89 \mathrm{c}$ & $31,5 \mathrm{c}$ & $1,74 b$ & $0,47 b$ & $63,7 \mathrm{~d}$ & $378,5 \mathrm{~d}$ & $78 \mathrm{a}$ \\
\hline
\end{tabular}

*Means followed by the same letter do not differ significantly at $\mathrm{p}=0.05$ according to Tukey multiple range

Table 4 Effect of numbers of $200 \mathrm{mg} \mathrm{L}^{-1}$ silicon (Actisil) applications on biochemical traits of greenhouse-grown petunia plants at the end of experiment $(\mathrm{n}=15$ plants per treatment)

\begin{tabular}{|c|c|c|c|c|c|c|c|}
\hline $\begin{array}{l}\text { Numbers of } 200 \mathrm{mg} \mathrm{L}^{-1} \\
\text { of Actisil applications }\end{array}$ & $\begin{array}{l}\text { Proline } \\
\left(\mu \mathrm{mol} \mathrm{g} \mathrm{g}^{-1}\right. \\
\text { fw })\end{array}$ & $\begin{array}{l}\text { MDA } \\
\left(n m o l g^{-1}\right. \\
\text { fw) }\end{array}$ & $\begin{array}{l}\text { Total chloro- } \\
\text { phylls }\left(\mu \mathrm{g} \mathrm{g}^{-1}\right. \\
\text { fw) }\end{array}$ & $\begin{array}{l}\text { Carotenoid } \\
\left(\mu \mathrm{g} \mathrm{g}^{-1} \mathrm{fw}\right)\end{array}$ & $\begin{array}{l}\text { Catalze CAT }(\mu \mathrm{M} \\
\left.\mathrm{H}_{2} \mathrm{O}_{2} \mathrm{~g}^{-1} \text { fw } \min ^{-2}\right)\end{array}$ & $\begin{array}{l}\text { Total polyphenol } \\
\text { mg }\left(\text { GAE } 100 \mathrm{~g}^{-1}\right)\end{array}$ & $\begin{array}{l}\mathrm{NO}_{3}(\mathrm{mg} \\
\left.1000 \mathrm{~g}^{-1}\right)\end{array}$ \\
\hline 0 & $3.72 b^{*}$ & $9.5 \mathrm{a}$ & $1.20 \mathrm{a}$ & $0.93 \mathrm{~d}$ & $47.3 \mathrm{a}$ & $355.2 \mathrm{ab}$ & $174 a$ \\
\hline 1 & $3.48 \mathrm{~b}$ & $11.2 \mathrm{ab}$ & $3.72 \mathrm{c}$ & $0.27 \mathrm{a}$ & $52.8 \mathrm{a}$ & $331.6 a$ & $328 d$ \\
\hline 2 & $2.44 \mathrm{a}$ & $14.8 \mathrm{~b}$ & $3.51 \mathrm{c}$ & $0.80 \mathrm{c}$ & $60.2 b$ & $380.6 \mathrm{~b}$ & $290 \mathrm{c}$ \\
\hline 3 & $15.25 \mathrm{c}$ & $18.4 \mathrm{c}$ & $1.99 b$ & $0.55 b$ & $68.9 \mathrm{c}$ & $438.9 c$ & $242 b$ \\
\hline
\end{tabular}

*Means followed by the same letter do not differ significantly at $\mathrm{p}=0.05$ according to Tukey multiple range

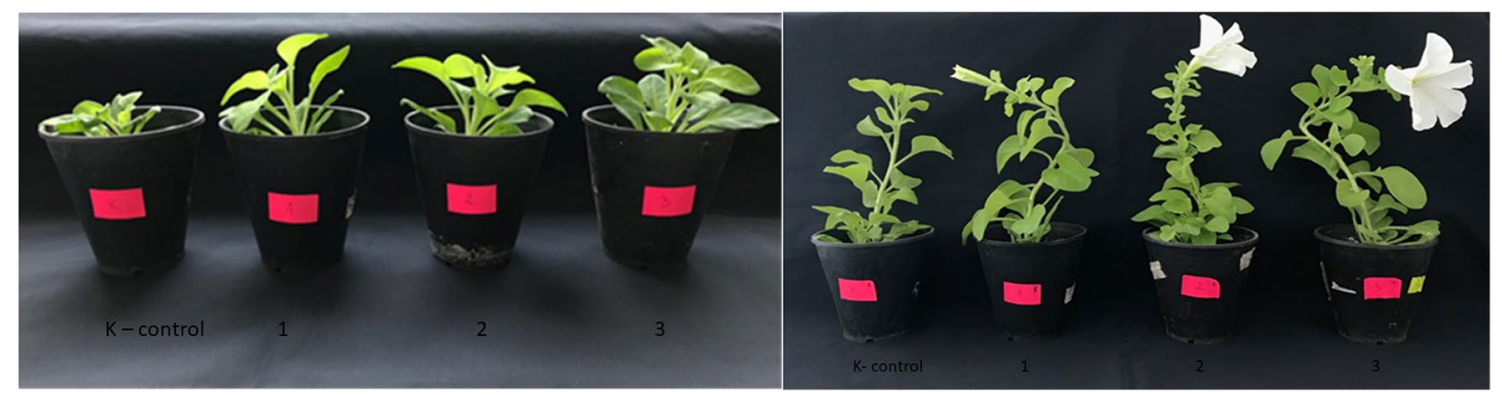

Fig. 1 Greenhouse-grown Petunia $\times$ atkinsiana D.don 'Prism White' plants after 2 weeks of acclimatization, before Actisil application (left) and after 6 weeks (right); K-control, 1-3 numbers of Actisil application

\section{Leaf colour and pigments}

The results of the colour determination of the leaves were analyzed in the transmitted mode using the photocolorimetric method in the CIE L*a*b* system (KrupaMałkiewicz et al. 2017). Content of photosynthetic pigments in petunia leaves is closely correlated to their colour. For the $\mathrm{a}^{*}$ values colour ranging from green (negative $a^{*}$ ) to red (positive $a^{*}$ ); and for the $b^{*}$ values - colour ranging from yellow (positive $b^{*}$ ) to blue (negative $b^{*}$ ). In this study, it was observed that the addition of Actisil solution to the MS medium affected the colour of the petunia leaves as compared to the control plants (Fig. 4A). It was evidenced by parameter $\mathrm{L}^{*}$, the value of which ranged from 8.43 to 11.81 compared to the control (7.90). The value of parameter $L^{*}$ (ranging from 0 to 100 , for black to white) is usually used for tracking colour changes and is related to the physiological attributes of the visual appearance of lightness (Krupa-Małkiewicz et al. 2017). It was observed that the addition of Actisil to the MS medium, regardless of concentration, had a positive influence on the intensity of the green colour (parameter $\mathrm{a}^{*}$ ) and yellow colour (parameter $b^{*}$ ) of petunia leaves grown in vitro. It was evidenced by parameter $\mathrm{a}^{*}$ and the chlorophyll content. Measured on the petunia leaf surface in vitro, those values ranged from -3.16 (MS $+50 \mathrm{mg} \mathrm{L}^{-1}$ Actisil) to $-6.41\left(\mathrm{MS}+200 \mathrm{mg} \mathrm{L}^{-1}\right)$. A similar relationship was 


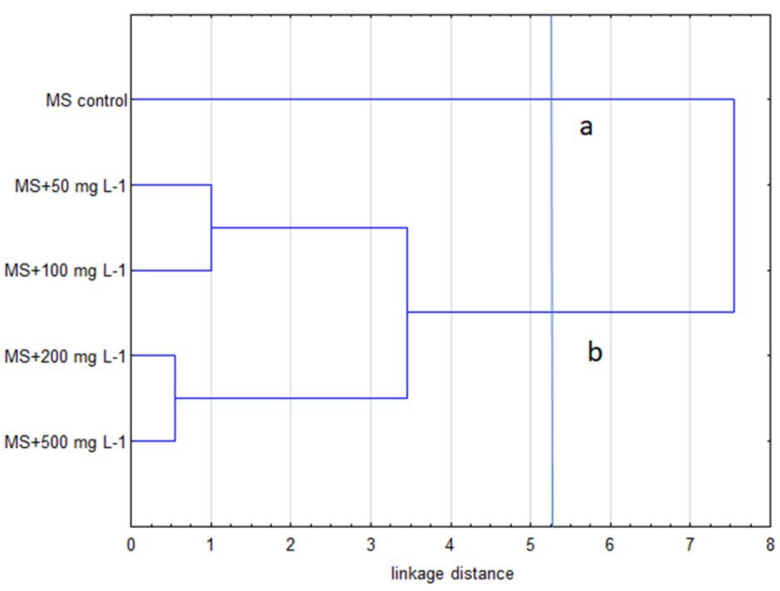

A

Fig. 2 Dendrogram of cluster analysis of morphological parameters in vitro petunia explants (A) and greenhouse-grown plants (B). The vertical line (linkage distance -5.5 and 6.1) indicates the cut-off used to form four groups (a, b)

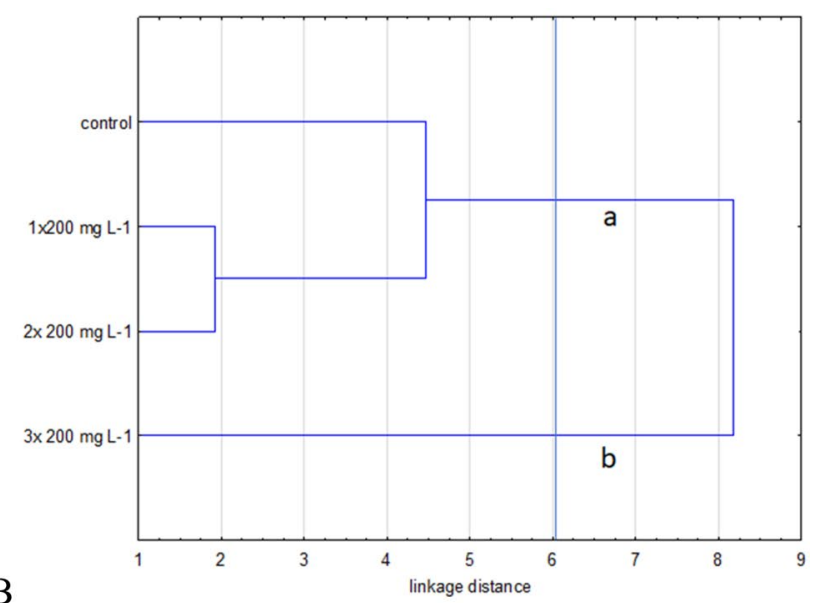

B

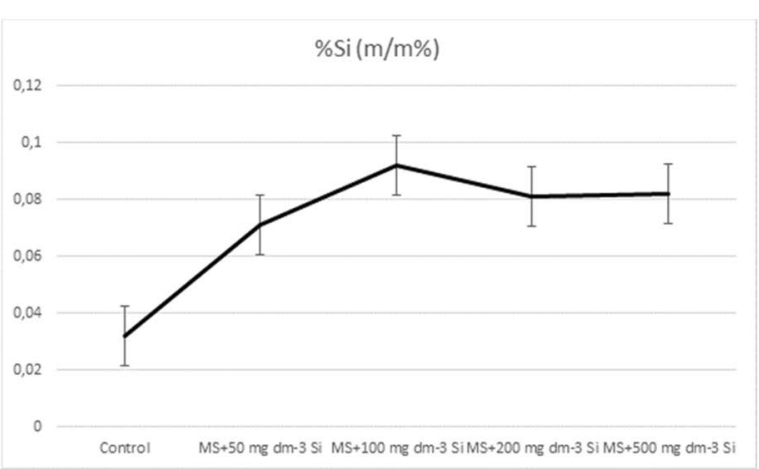

A

Fig. 3 Effect of (A) different Actisil concentrations in the MS medium of in vitro grown petunia explants and (B) number of $200 \mathrm{mg}$ $\mathrm{L}^{-1}$ Actisil applications via irrigation of greenhouse-grown petunia plants, on silicon concentration $(\mathrm{m} / \mathrm{m} \%)$ in petunia shoots at the end of the experiment. The figure: indicate with $\mathrm{A}$ and $\mathrm{B}$, in $\mathrm{A}$ : legend of

observed for the content of chlorophyll in petunia under in vitro culture (Table 3). The content of total chlorophyll increased when the concentration of Actisil increased in MS medium and was the highest (177\% of the control) in the concentration recommended by the producer (200 $\mathrm{m} \mathrm{L} \mathrm{L}^{-1}$ ). It was also observed that additions to the MS medium of $500 \mathrm{mg} \mathrm{L}^{-1}$ of Actisil significantly reduced the total chlorophyll content in petunia leaves, which was similar to the level of the control plant (Table 3). The leaf surface colour defined by $b^{*}$ indicates the location along the axis between yellow and blue. Petunia leaves growing in the MS medium with the addition of Actisil indicated a higher value of parameter $b^{*}(8.42-11.81)$ as compared to the control plants (7.90). Carotenoids are important phytonutrients responsible for the yellow endosperm colour

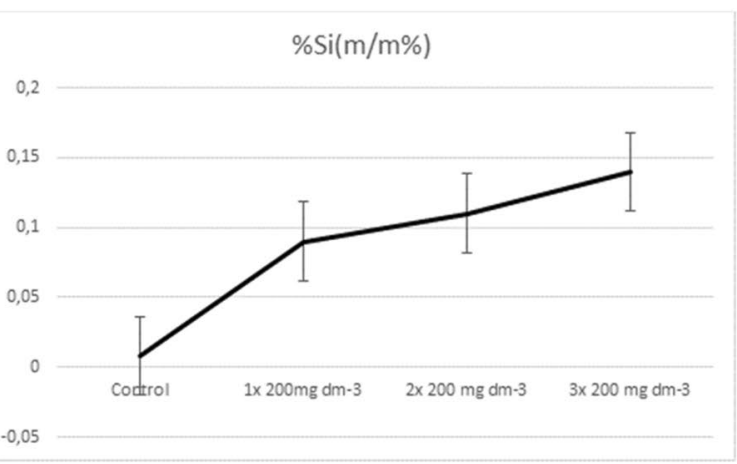

B

x-axis: 0 (control), 50, 100, 200, $500 \mathrm{mg} \mathrm{L}^{-1}$ ) of Actisil concentration, $\mathrm{n}=48$ shoots per treatments; in B: legend of $\mathrm{x}$-axis: 0 (control), $1,2,3$ no. of $200 \mathrm{mg} \mathrm{L}^{-1}$ Actisil applications, $\mathrm{n}=15$ plants per treatments

in plant tissue. Also, carotenoids are antioxidants that protect cells from reactive oxygen species and free radicals (Krupa-Małkiewicz and Smolik 2019). In this study, the reverse effect of Actisil was observed for carotenoid content in plants in vitro, which was $70-23 \%$ lower than that of the control (Table 3).

In greenhouse-grown petunia the leaves of control plants were darker, which is shown by the lower value of the parameter $\mathrm{L}^{*}$ (23.04). It was observed that in response to an increasing number of Acitisil irrigation the value of parameter $\mathrm{L}^{*}$ decreased (Fig. 4b). Similar, there were significant linear decreases in parameter $\mathrm{a}^{*}$ (from -10.16 to -7.46 ) and parameter $b^{*}$ (from 24.57 to 14.21 ), which determined the colour of the petunia leaves, in response to increasing number of Actisil irrigations. A similar 


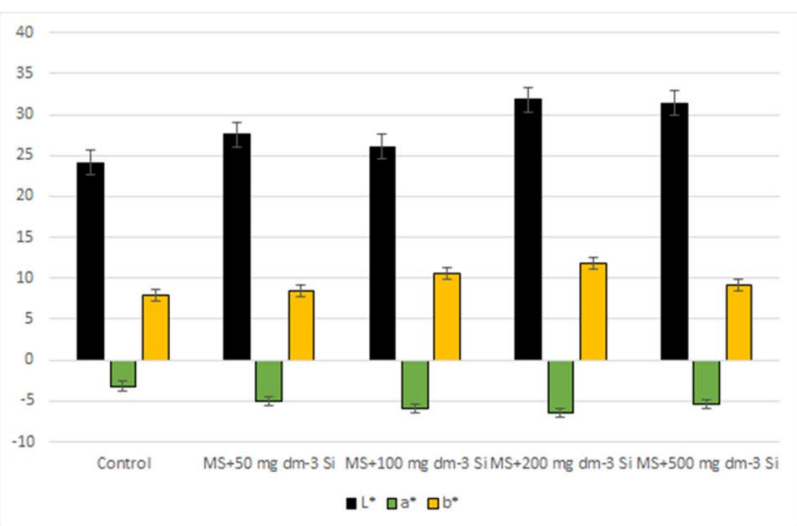

A

Fig. 4 Effect of (A) different Actisil concentrations in the MS medium of in vitro grown petunia explants and (B) number of $200 \mathrm{mg}$ $\mathrm{L}^{-1}$. Actisil applications via irrigation of greenhouse-grown petunia plants, on leaves colour using CIE $L^{*} a^{*} b^{*}$ system, $L^{*}$ the lightness coefficient, $a^{*}$ (green colour), and $b^{*}$ (yellow colour) at the end of the

relationship was observed for the content of chlorophyll in greenhouse-grown petunia leaves. The concentration of total chlorophyll increased three times $(310 \%$ of the control) after one application of Actisil (Table 4). However, when the number of applications increased, the total chlorophyll content decreased, and after the third application was only $50 \%$ higher than in the untreated plants (control). Moreover, irrigation of $200 \mathrm{mg} \mathrm{L}^{-1}$ Actisil decreased carotenoid content in petunia leaves which were lower from 14 to $70 \%$ than the control $\left(0.93 \mu \mathrm{g}^{-1}\right.$ fw) (Table 4).

In the studies of Lim et al. (2012), after application of $100 \mathrm{mg} \mathrm{L}^{-1}$ of potassium silicate in MS medium, chlorophyll content was significantly greater in both examined cultivars of begonia ('Super Olympia Red' and 'Super Olympia Rose'). In the case of pansy, chlorophyll content increased after Si application in 'Matrix White Blotch', whereas in 'Matrix Yellow Blotch' it decreased. The study conducted by Barbosa et al. (2015) of maize plants under Si treatment showed an increase in chlorophylls and a decrease in carotenoids, corroborating this study. Furthermore, Zhang et al. (2018) found a positive effect on chlorophyll concentrations in tomato leaves, after the addition of $2.5 \mathrm{mmol} \mathrm{L}^{-1}$ of potassium silicate into the Hoagland medium. On the contrary, Whitted-Haag et al. (2014) reported that there was no significant effect on 'Celebrity White' petunias in the chlorophyll SPAD content. According to Barbosa et al. (2015), Zhang et al. (2018), Mandlik et al. (2020) the increase in total chlorophyll content normally is associated with improvement in light interception and better performance of the photosynthetic parameters.

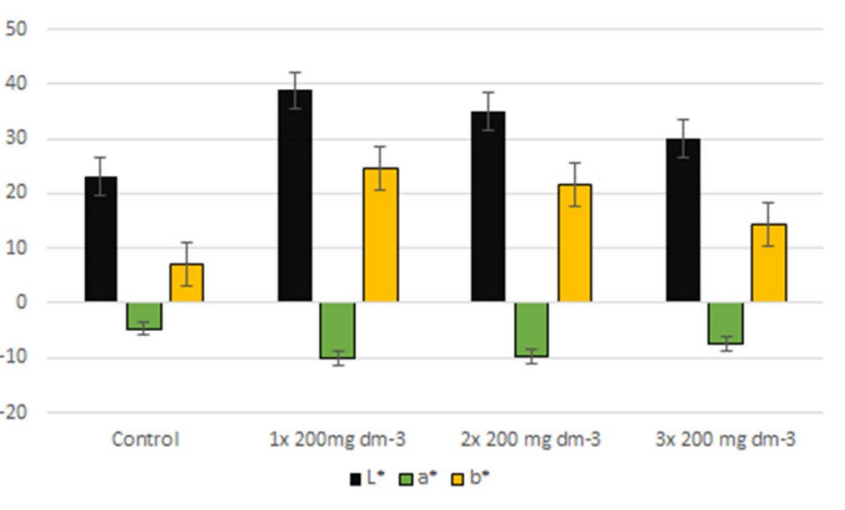

B

experiment. The figure: indicate with $\mathrm{A}$ and $\mathrm{B}$, in $\mathrm{A}$ : legend of $\mathrm{x}$-axis: 0 (control), 50, 100, 200, $500 \mathrm{mg} \mathrm{L}^{-1}$ ) of Actisil concentration, $\mathrm{n}=48$ shoots per treatments; in B: legend of x-axis: 0 (control), 1, 2, 3 no. of $200 \mathrm{mg} \mathrm{L}^{-1}$ Actisil applications, $\mathrm{n}=15$ plants per treatments

\section{Biochemical parameters of stress response}

According to Barbosa et al. (2015) and Krupa-Małkiewicz and Smolik (2019) MDA is an end product that is produced as a result of lipid peroxidation damage by free radicals. Proline accumulation is one of the most frequently reported modifications induced by environmental stresses. The addition of Actisil to the MS medium increased MDA (from 26 to 158\%) and proline (from 150 to $1200 \%$ ) concentration in leaves of in vitro grown petunia in comparison to the control (Table 3). Similarly, in greenhousegrown petunia irrigated with $200 \mathrm{mg} \mathrm{L}^{-1}$ Actisil increased MDA concentration from 17 to $93 \%$ compared to the control (Table 4). In contrast, proline concentration decreased when irrigation the second time of Actisil, but significantly increased (41\% in comparison to the control) after the third Actisil application. In this study, the increase in Actisil concentration promoted a slight increase in MDA values. This fact can be attributed to a decrease in membrane permeability and, consequently, low MDA accumulation after Si application (Barbosa et al. 2015). Similar results were reported by Mohsenzadeh et al. (2011), using Si in Zea mays plants. Kim et al. (2014), investigated Oryza sativa plants and observed minor values of MDA in the root after Si treatment, as also described in this study. Shekari et al. (2017) reported that Si treatment at a concentration of $1.5 \mathrm{mM}$ increased MDA and proline content in dill by 33 and $15 \%$, respectively when compared to the control plants grown without $\mathrm{Si}$.

Catalase (CAT) is the major antioxidant enzyme associated with scavenging reactive oxygen species (ROS) 

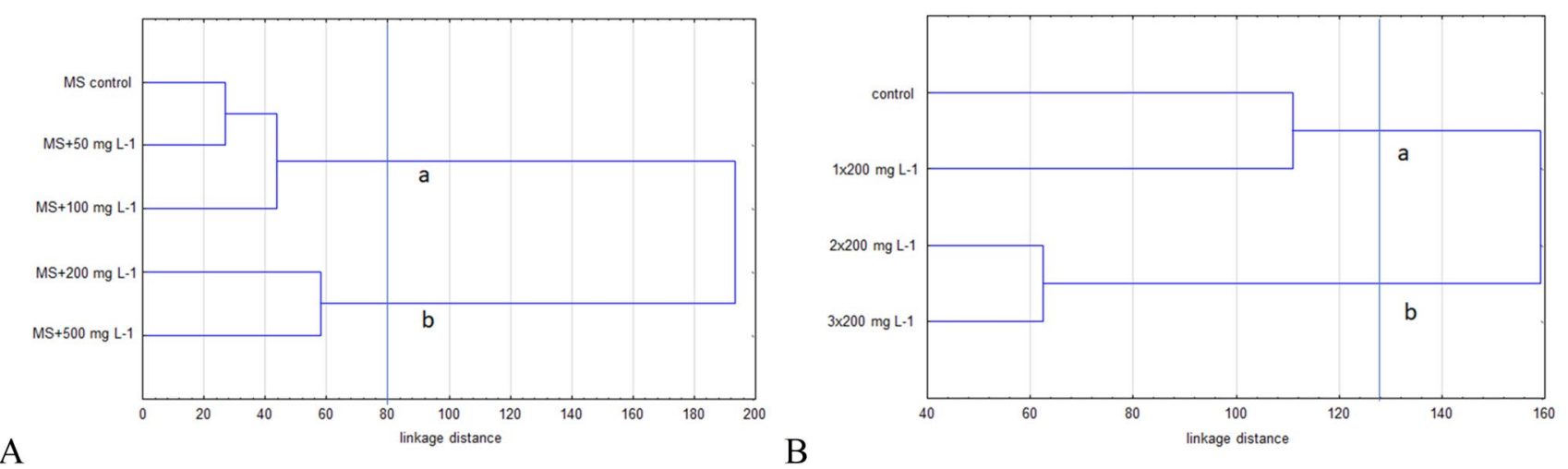

Fig. 5 Dendrogram of cluster analysis of biochemical parameters in vitro petunia explants (A) and greenhouse-grown plants (B). The vertical line (linkage distance -80 and 125) indicates the cut-off used to form four groups (a, b)

(Shekari et al. 2017; Sędzik et al. 2018). The addition of Actisil in the MS medium in a concentration of 200 and $500 \mathrm{mg} \mathrm{L}^{-1}$ significantly increased CAT activity (19 and $51 \%$, respectively) in the petunia leaves when compared to the control plants (Table 3). Similarly, in greenhousegrown petunia leaves CAT activity increased (from 12 to $46 \%$ ) when the numbers of irrigation increased (Table 4). Thus, it appears that ROS production was higher than its scavenging by antioxidants. Activation of catalase also coincided with an increase in the concentration of MDA, suggesting that oxidative damage may be induced by the addition of Actisil. The results of this study are in line with previous findings which showed that the addition of $\mathrm{Si}$ increased the CAT activity in pistachio (Habibi and Hajlboland 2013) and dill (Shekari et al. 2017).

Polyphenols are secondary metabolites of plants and are generally involved in defense against biotic and abiotic stresses. Also, plant polyphenols are natural antioxidants and are considered to have protective effects to quench singlet oxygen (Chensom et al. 2019; Kruczek et al. 2020). According to Dragišic Maksimovic et al. (2007) the deposition of $\mathrm{Si}$ in higher plants is associated with co-precipitation of $\mathrm{Si}$ and lignin which can be induced by the polymerization of phenols. There were considerable differences in the total polyphenol content (TPC) of the analysed petunia plants. The highest TPC was observed in petunia grown on MS medium with the addition of $500 \mathrm{mg} \mathrm{L}^{-1}$ of Actisil (163\% of the control plants) (Table 3), and in greenhouse-grown plants after the third irrigation of Actisil (124\% of the control plant) (Table 4). It was also observed that the TPC was increased when the concentration of Si increased in both in vitro and greenhouse conditions. Furthermore, the control plants of petunia propagated in vitro were characterized by a lower content of TPC ( $\left.231.8 \mathrm{mg} \mathrm{GAE} 100 \mathrm{~g}^{-1}\right)$ compared to greenhouse-grown control plants of petunia (355.2 mg GAE $100 \mathrm{~g}^{-1}$ ). An earlier study by Chensom et al. (2019) revealed $1.47 \mathrm{mg} \mathrm{GAE} \mathrm{g}^{-1} \mathrm{fw}$ in petunia flowers.
Cluster analysis conducted using Ward's method (Fig. 5A, B) permitted the isolation of two groups with a similar influence on the biochemical parameters of the petunia plants tested. The analysis showed that higher concentrations of Actisil in MS medium (200 and $500 \mathrm{mg} \mathrm{L}^{-1}$ ) - group b, had a different effect on the traits studied compared to the control plants and lower concentrations of Actisil (50 and $100 \mathrm{mg}$ $\mathrm{L}^{-1}$ ) - group a (Fig. 5A). Similar, greenhouse-grown petunia plants with the highest number of irrigation represented group b (Fig. 5B). When control plants and petunia after one time of Actisil application represented group a.

\section{Conclusions}

The beneficial effects of Actisil on petunia (as a non-accumulator of silicon) suggest a possible involvement of silicon in the physiological and/or biochemical processes, rather than a physical barrier, as suggested in silicon accumulators. The results also suggest that commercial silicon solution (Hydroplus ${ }^{\mathrm{TM}}$ Actisil) supplementation influences the growth and biochemical parameters of petunia plants under in vitro and greenhouse conditions. However, the effect varied among concentrations, methods of application, the plant parts, and the developmental and growth processes that are targeted. Although in vitro Actisil solution possibly acts as a stress factor, which was confirmed by the obtained biochemical results, a positive aspect was the appearance of flowers. Therefore, the dose of $200 \mathrm{mg} \mathrm{L}^{-1}$ Actisil recommended by the producer met expectations. The greenhouse-grown petunia plants irrigated by $200 \mathrm{mg} \mathrm{L}^{-1}$ Actisil were the tallest plant with the longest roots and the highest number of flowers. Moreover, the data presented herein indicate that the petunia also has high concentrations of polyphenols and antioxidant compounds. 
Author contributions Material, M.K-M., conceptualization, M.K-M., methodology, M.K-M., M.C.; formal analysis, M.K-M., M.C.; writingoriginal draft preparation, M.K-M., writing-review and editing, M.KM., visualization, M.K-M.

Funding This research was supported by the West Pomeranian University of Technology Grant No. 503-07-081-09/4.

\section{Declarations}

Conflict of interest The authors declare no conflict of interest. The funders had no role in the design of the study; in the collection, analyses, or interpretation of data; in the writing of the manuscript, or in the decision to publish the results.

Open Access This article is licensed under a Creative Commons Attribution 4.0 International License, which permits use, sharing, adaptation, distribution and reproduction in any medium or format, as long as you give appropriate credit to the original author(s) and the source, provide a link to the Creative Commons licence, and indicate if changes were made. The images or other third party material in this article are included in the article's Creative Commons licence, unless indicated otherwise in a credit line to the material. If material is not included in the article's Creative Commons licence and your intended use is not permitted by statutory regulation or exceeds the permitted use, you will need to obtain permission directly from the copyright holder. To view a copy of this licence, visit http://creativecommons.org/licenses/by/4.0/.

\section{References}

Armon DJ, Allen MB, Whatley F (1956) Photosynthesis by isolated chloroplast. Biochim Biophys Acta 20:449-461

Asmar SA, Castro EM, Pasqual M et al (2013) Changes in leaf anatomy and photosynthesis of micropropagated banana plantlets under different silicon sources. Sci Hort 161:328-332. https://doi.org/ 10.1016/j.scienta.2013.07.021

Barbosa MAM, da Silva MHL, Viana GDM et al (2015) Beneficial repercussion of silicon $(\mathrm{Si})$ application on photosynthetic pigments in maize plants. Aust J Crop Sci 9(11):1113

Bates LS, Waldren R, Teare I (1973) Rapid determination of free proline for water-stress studies. Plant Soil 39(1):205-207

Boldt JK, Locke JC, Altland JE (2018) Silicon accumulation and distribution in petunia and sunflower grown in a rice hull-amended substrate. HortSci 53(5):698-703. https://doi.org/10.21273/HORTS CI12325-17

Braga FT, Nunes CF, Favero AC et al (2009) Anatomical characteristics of the strawberry seedlings micropropagated using different sources of silicon. Pesqui Agropecu Bras 44(2):128-132. https:// doi.org/10.1590/S0100-204X2009000200003

Chensom S, Okumura H, Mishima T (2019) Primary screening of antioxidant activity, total polyphenol content, carotenoid content, and nutritional composition of 13 edible flowers from Japan. Prev Nut Food Sci 24(2):171-178. doi:https://doi.org/10.3746/pnf.2019. 24.2.171

da Silva DPC, de Oliveira Paiva PD, Herrera RC et al (2020) Effectiveness of silicon sources for in vitro development of gerbera. Plant Cell Tissue Organ Cult. https://doi.org/10.1007/ s11240-020-01768-8

Dragišić Maksimović J, Bogdanović J, Maksimović V, Nikolic M (2007) Silicon modulates the metabolism and utilization of phenolic compounds in cucumber (Cucumis sativus L.) grown at excess manganese. J Plant Nutri Soil Sci 170(6):739-744. https:// doi.org/10.1002/jpln.200700101

Druege U, Franken P (2019) Petunia as model for elucidating adventitious root formation and mycorrhizal symbiosis: at the nexus of physiology, genetics, microbiology and horticulture. Physiol Plant 165(1):58-72

Epstein E (1994) The anomaly of silicon in plant biology. Proc Natl Acad Sci USA 91:11-17. https://doi.org/10.1073/pnas.91.1.11

Folin-Franklin G, Pius PK, Ignacimuthu S (2000) Factors affecting in vitro flowering and fruiting of green pea (Pisum sativum L.). Euphytica 115:65-74

Frantz JM, Locke JC, Datnoff L et al (2008) Detection, distribution, and quantification of silicon in floricultural crops utilizing three distinct analytical methods. Commun Soil Sci Plant Anal 39(1718):2734-2751. https://doi.org/10.1080/00103620802358912

Frantz JM, Khandekar S, Leisner S (2011) Silicon differentially influences copper toxicity response in silicon-accumulator and non-accumulator species. J Am Soc Hortic Sci 136(5):329-338. https://doi.org/10.21273/JASHS.136.5.329

Habibi G, Hajiboland R (2013) Alleviation of drought stress by silicon supplementation in pistachio (Pistacia vera L.) plants. Folia Hort 25(1):21-29. https://doi.org/10.2478/fhort-2013-0003

Hendry GAF, Grime JP (1993) Methods in Comparative Plant Ecology. Marcel Dekker Inc., New York

Hunterlab: Measuring Color using Hunter L, a, b versus CIE 1976 L*a*b* (2012) AN 1005.00, pp. 1-4. www.hunterlab.com/an1005b.pdf

Kamenidou S, Cavins TJ, Marek S (2008) Silicon supplements affect horticultural traits of greenhouse-produced ornamental sunflowers. HortSci 43(1):236-239. https://doi.org/10.21273/HORTSCI. 43.1.236

Kim YH, Khan AL, Waqas M, Jeong HJ, Kim DH, Shin JS, Kim JG, Yeon MH, Lee IJ (2014) Regulation of jasmonic acid biosynthesis by silicon application during physical injury to Oryza sativa L. Plant Res 127(4):525-532. DOI https://doi.org/10.1007/ s10265-014-0641-3

Kruczek A, Ochmian I, Krupa-Małkiewicz M, Lachowicz S (2020) Comparison of morphological, antidiabetic and antioxidant properties of goji fruits. Acta Univ Cibiniensis Ser E, Food Technol. https://doi.org/10.2478/aucft-2020-0001

Krupa-Małkiewicz M, Mgłosiek O (2016) Influence of sugar, ammonium nitrate and plant growth regulators on in vitro flowering of Celosia argentea var. cristata. J Basic App Sci 12:135-139

Krupa-Małkiewicz M, Kosatka A, Smolik B, Sędzik M (2017) Induced mutations through EMS treatment and in vitro screening for salt tolerance plant of Petunia $\times$ atkinsiana D. Don. Not Bot Horti Agrobot Cluj-Napoca 45(1):190-196. https://doi.org/10.15835/ nbha45110578

Krupa-Małkiewicz M, Smolik B (2019) Alleviative effects of chitosan and ascorbic acid on Petunia $\times$ atkinsiana D. Don. under salinity. Eur J Hortic Sci 84(6):359-365. https://doi.org/10.17660/eJHS. 2019/84.6.5

Lichtenthaler HK, Wellburn AR (1983) Determinations of total carotenoids and chlorophylls a and b of leaf extracts in different solvents. Biochem Soc Trans 11:591-592

Lim MY, Lee EJ, Jana S, Sivanesan I, Jeong BR (2012) Effect of potassium silicate on growth and leaf epidermal characteristics of begonia and pansy grown in vitro. Hort Sci Technol 30(5):579585. https://doi.org/10.7235/hort.2012.12062

Luyckx M, Hausman J F, Lutts S, Guerriero G (2017) Silicon and plants: current knowledge and technological perspectives. Front Plant Sci 8:411

Lück H (1963) Catalase. In: Bergmeyer HU (ed) Methods of enzymatic analysis. Verlag Chemie, pp. 885-888 
Mandlik R, Thakral V, Raturi G et al (2020) Significance of silicon uptake, transport, and deposition in plants. J Exp Bot 71(21):6703-6718

Mattson NS, Leatherwood WR (2010) Potassium silicate drenches increase leaf silicon content and affect morphological traits of several floriculture crops grown in a peat-based substrate. HortSci 45(1):43-47. https://doi.org/10.21273/HORTSCI.45.1.43

Mohsenzadeh S, Shahrtash M, Mohabatkar H (2011) Interactive effects of salicylic acid and silicon on some physiological responses of cadmium-stressed maize seedlings. Iran J Sci Technol 35(1):5760. https://doi.org/10.22099/ijsts.2011.2129

Murashige T, Skoog F (1962) A revised medium for rapid growth and bioassay with tobacco tissue culture. Physiol Plant 15:473-497

Ochmian I, Błaszak M, Lachowicz S, Piwowarczyk R (2020) The impact of cultivation systems on the nutritional and phytochemical content, and microbiological contamination of highbush blueberry. Sci Rep 10(1):1-14

Price AH, Hendry GA (1991) Ion-catalyzed oxygen radical formation and its possible contribution to drought damages in nine native grasses and three cereals. Plant Cell Environ 14(5):477-484

Sahebi M, Hanafi MM, Azizi P (2016) Application of silicon in plant tissue culture. In Vitro Cell Dev Biol Plant 52(3):226-232

Savvas D, Manos G, Kotsiras A, Souvaliotis S (2002) Effects of silicon and nutrient-induced salinity on yield, flower quality and nutrient uptake of gerbera grown in a closed hydroponic system. J App Bot 76(5/6):153-158

Sędzik M, Smolik B, Krupa-Małkiewicz M (2019) Effect of nicotinamide in alleviating stress caused by lead in spring barley seedling. J Elem 24(1):281-291. https://doi.org/10.5601/jelem.2018.23.2. 1582

Shekari F, Abbasi A, Mustafavi SH (2017) Effect of silicon and selenium on enzymatic changes and productivity of dill in saline condition. J Saudi Soc Agric Sci 16(4):367-374. https://doi.org/10. 1016/j.jssas.2015.11.006

Sivanesan I, Won Park S (2014) The role of silicon in plant tissue culture. Front Plant Sci 5:57. https://doi.org/10.3389/fpls.2014.00571
Soares JDR, Pasqual M, Rodrigues FA, Villa F, de Araujo AG (2011) Silicon sources in the micropropagation of the Cattleya group orchid. Acta Sci Agron 33(3):503-507. https://doi.org/10.4025/ actasciagron.v33i3.6281

Sudhakar C, Lakshim A, Giridarakumar S (2001) Changes in the antioxidant enzyme efficacy in two high yielding genotypes of mulberry (Morus alba L.) under $\mathrm{NaCl}$ salinity. Plant Sci 161:613-619. https://doi.org/10.1016/S0168-9452(01)00450-2

Vaculík M, Lux A, Luxová M, Tanimoto E, Lichtscheidl I (2009) Silicon mitigates cadmium inhibitory effects in young maize plants. Environ Exp Bot 67(1):2-58.9. https://doi.org/10.1016/j.envex pbot.2009.06.012

Vandenbussche M, Chambrier P, Bento SR, Morel P (2016) Petunia, your next supermodel? Front Plant Sci 7:72. https://doi.org/10. 3389/fpls.2016.00072

Voogt W, Sonneveld C (2001) Silicon in horticultural crops grown in soilless culture. In: Datnoff LE, Snyder GH, Kornd"orfer GH (eds) Silicon in agriculture. Elsevier, Amsterdam, pp 115-131

Whitted-Haag B, Kopsell DE, Kopsell DA, Rhykerd RL (2014) Foliar silicon and titanium applications influence growth and quality characteristics of annual bedding plants. Open Hort J. https://doi. org/10.2174/1874840601407010006

Zhang T (2007) Studies on in vitro flowering and fruiting of Perilla frutescens. Agric Sci China 6:33-37. https://doi.org/10.1016/ S1671-2927(07)60014-5

Zhang Y, Yu SHI, Gong HJ et al (2018) Beneficial effects of silicon on photosynthesis of tomato seedlings under water stress. J Integr Agric 17(10):2151-2159. https://doi.org/10.1016/S2095-3119(18) 62038-6

Publisher's note Springer Nature remains neutral with regard to jurisdictional claims in published maps and institutional affiliations. 